\title{
Biochemical and phytochemical studies on Balanities aegyptiaca fruits
} \author{
mostufa badawy

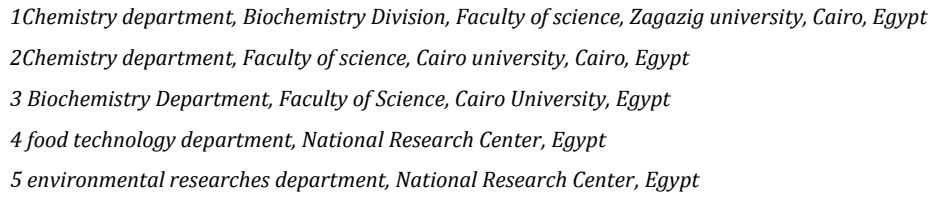

Faten Zahran Mohamed ${ }^{1}$, Abdelgawad Ali Fahmi ${ }^{2}$, Amr Saad ${ }^{3}$, Fathy Mohamed Mehaya ${ }^{4}$ and Esraa ahmed ${ }^{5}$

\begin{tabular}{l}
\hline A R T ICLE INF O \\
\hline Balanities aegyptiaca, \\
phytochemical screening, \\
invitro anti-inflammatory, \\
antitumor activity.
\end{tabular}
octivity.

A B S R A C T
Objectives: Phytochemical screeninig of Balanities
aegyptiaca (B.a.) extract and invitro determination of some
biochemical effects. Methods: preparation of defatted
Balanities aegyptiaca total extract, it's characterization was
done throughout Firstly, quantitative and qualitative
determination of active phenolic components by HPLC and
spectrophotometer analysis. Secondly, identification of
different function groups by IR analysis and surface
elements by electronic microscope, then estimation for
saponins content by spectrophotometer, After that estimation
of total flavonoids, carbohydrates and proteins. Finally,
determination of B. a. extract antioxidant activity by using
DPPH, anti-inflammatory activity and antitumor activity
using (MCF-7) human breast adenocarcinoma cell line.
Results: This study revealed that total extract of Balanities
fruits showed high levels of antioxidants as each 1 gram
contained 10 mg of ascorbic acid and anti-inflammatory
activities as it inhibited NO production by $60 \%$ compared to
positive control group. Also, it revealed high
antiproliferation activity IC50=21.2 ug/ml correlated with its
phytochemical screening which showed the presence of high
levels of phenolics, flavnoids, minerals (Zn, Mg, Ca, K, Na,
Fe, Cl, Al, Si, O and Carbon) and Saponins. Conclusion:
Balanities aegyptiaca extract plays an important role in
improving oxidative stress resulted in high antiproliferation
activity against (MCF-7) and posses a strong anti-
inflammatory agent, Furthermore purification and isolation
of active compounds will help in recommendation of new
antinflammatory and antitumor herbal treatments.

() 2015 Publisher All rights reserved.

\section{INTRODUCTION}

Medicinal plants contain various phytochemicals that are used for treatment of various diseases.
Anti-oxidants present in the plants play an essential role in protecting the cells and tissues against damage caused by oxidative stress ${ }^{(1)}$. 
Oxidative stress is the imbalance between excess generation of free radicals and the inability of the body's antioxidant defense system to eliminate the radicals (2). Reactive oxygen species (ROS) such as superoxide anion $\left(\mathrm{O}_{2}^{-}\right)$, superoxide hydroxyl $\left(\mathrm{OH}^{-}\right)$, peroxyl radical ( $\left.\mathrm{RO}^{-}\right)$and hydrogen peroxide $\left(\mathrm{H}_{2} \mathrm{O}_{2}\right)$ are just some of the major free radical species that are implicated in the pathogenesis of various diseases ${ }^{(3)}$. Excessive generation of ROS can have detrimental effects, including damage to lipids, deoxyribonucleic acid DNA or proteins (4).

Balanites aegyptiaca, a forest species of socio-economic interest for rural people. The dietary intake of this fruit for local people is very valuable especially in terms of nutrition ${ }^{(5)}$ It is known as 'desert date' is a spiny shrub or tree up to 10 meter tall, widely distributed in dry land areas of Africa and South Asia. It is traditionally used in treatment of various ailments such as jaundice, intestinal worm infection, wounds, malaria and epilepsy, insanity, yellow fever, syphilis, helminthiasis, cough, and constipation (6). It contains protein, lipid, carbohydrate, alkaloid, saponin, flavonoid, and organic acid ${ }^{(7)}$.

The presence of different phyto-chemicals such as cardiac glycosides, flavornoids and polyphenols, has provi-ded some biochemical basis for ethno pharmacological uses of the (B. a.) parts in the treatment and prevention of various diseases and disorders ${ }^{(8)}$. The mesocarp of (B. a.) fruit basically contains 1.2 to $1.5 \%$ proteins, 35 to $37 \%$ sugars and $15 \%$ organic acids. Chemical analysis of (B. a.) revealed other compounds such as 3-rutinoside and 3rhamnogalactoside, diosgenin and a mixture of $22 \mathrm{R}$ and $22 \mathrm{~S}$ epimers of $26-(\mathrm{O}-\beta-\mathrm{D}-$ lucopyranosyl)-3- $\beta$-[4-O-( $\beta$-D-glucopyranosyl)$2-\mathrm{O}-(\alpha$-L-rhamnopy-ranosyl)- $\beta$ -

glucopyranosyloxy]-22,26-dihydroxyfurost-5-en (9,10). Observed antioxidant, xanthine oxidase and acety-lcholinesterase inhibitory activity of leaves. Also, Saponins are well known as protective agents. Saponin comp-ounds are also considered responsible for numerous pharmacological properties including anticarcinogenic activity ${ }^{(11)}$. Saponins of several herbs are known to induce apoptosis in some cancer cells and are proposed to be promising modulators of drug resistance ${ }^{(\mathbf{1 3 )} \text {. }}$

Our present study was undertaken to identify bioactive compounds in (B. a.) fruit total extraction and aimed to determine its antioxidant and anti-inflammatory activities.

\section{Material and methods: Chemicals:}

Methanol, hexane and ethyle acetate (plant extraction solvents) were purchased from TEDIA Company, USA. Human breast adinocarcinoma cell line (MCF-7) was purchased from ATCC, USA. Biochemical kits were purchased from SIGMA-ALDRICH Company, EGYPT and all other chemicals were of the highest grade commercially available.

\section{Collection and Preparation of fruits:}

Balanites aegyptiaca was was purchased from Aswan (halaib date), Egypt. The fruits of (B. a.) were kindly identified and proved by Herbarium of Botany department, faculty of Science, Zagazig University. The fruits were dehydrated and ground into uniform powder using milling machine and keep in dark to prevent the loss of active components until extraction and analysis ${ }^{(14) .}$

\section{Extraction of Plant:}

Collected fruits were properly washed in water, rinsed using distilled water. The outer cover (The epicarp ) was removed by using sterile sharp surgical blade and the fruit pulps/ mesocarps were scarped manually then air dried under shade for about four months then the dried specimens were manually ground into powder using pestle and mortar ${ }^{(15)}$. Exposure to sunlight was avoided to prevent the loss of active components ${ }^{(14) .}$

One thousand gram of fruits mesocarp powder was defatted with $2000 \mathrm{ml}$ of n-hexane. The filtrate was extracted by soaking in $2000 \mathrm{ml}$ 
methanol for up to $72 \mathrm{~h}$. and, filtered twice with filter paper (Whatman No. 1). Then, the remaining was rextracted with $2000 \mathrm{ml}$ ethyl acetate. The filtrate (Methanol and ethyl acetate extracts) were combined and evaporated using a rotary evaporator (at $40^{\circ} \mathrm{C}$ ) to give semi-solid residues and transferred to freeze dryer to dry. This method was described as (1) with slight modification.

\section{First part: Characterization of Balanites aegyptiaca extract:}

1. a. Determination of phenolic comp-ounds in Balanites aegyptiaca extract by High Performance Liquid Chro-matography (HPLC):

Identification and determination of the phenolic compounds present in Balanities aegyptiaca were performed using HPLC system was a HP 1100 chromatograph (Agilent Technologies, Palo Alto, CA, USA) equipped with an auto-sampler; quaternary pump and a diode array detector were used. The quantitation was integrated by Chemst-ation chromatographic software inter-faced to a personal computer. The analy-tical column was ZORBAX Eclipse XDB C18 column (15 cm x $4.6 \mathrm{~mm}$ I.D., $5 \mu \mathrm{m}$, USA). The mobile phase consists of: mobile phase A, methanol; mobile phase B, $2 \%$ acetic acid; flow, $1 \mathrm{~mL}$ min; fixed wavelength, $280 \mathrm{~nm}$, with gradient elution program, $\mathrm{A}(\%) / \mathrm{B}(\%)$ : $0 \min 5 / 95 ; 5 \min 25 / 75$;

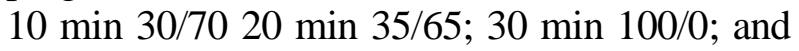
back to initial ratio in $10 \mathrm{~min}$. Identification of phenol compounds was performed by compareson with the retention times of standard substances ${ }^{(16) .}$

\section{1. b. Determination of total phenolic compounds in Balanites aegyptiaca extract by Spectrophotometer:}

The total phenolic content of fruits was determined by using the Folin-Ciocalteu assay (17). An aliquot $(1 \mathrm{ml})$ of extracts or standard solution of gallic acid (20, 40, 60, 80 and 100 $\mathrm{mg} / \mathrm{l})$ was added to $25 \mathrm{ml}$ volumetric flask, containing $9 \mathrm{ml}$ of deionized water. A reagent blank using $\mathrm{H}_{2} \mathrm{O}$ was prepared. One milliliter of Folin-Ciocalteu's phenol reagent was added to the mixture and shaken. After $5 \mathrm{~min}, 10 \mathrm{ml}$ of $7 \% \mathrm{Na}_{2} \mathrm{CO}_{3}$ solution was added to the mixture. The solution was diluted to volume $(25 \mathrm{ml})$ with $\mathrm{H}_{2} \mathrm{O}$ and mixed. After incubation for $90 \mathrm{~min}$ at ambient temperature, the absorbance against prepared reagent blank was determined at 750 $\mathrm{nm}$ with an UV-Vis Spectro-photometer Lambda 5. Total phenolic content of fruits was expressed as $\mathrm{mg}$ gallic acid equivalents (GAE/100 g fresh weight). All samples were analyzed in triplicates.

\section{Extraction and Determination of total saponins in Balanites aegyptiaca extract by Spectrophotometer:}

Take $25 \mathrm{~g}$ defatted sample in $500 \mathrm{ml}$ conical flask and add $250 \mathrm{ml}$ absolute methanol (99.9\%) in ratio of dry weight of the sample to methanol as 1:10. Flask was tightly sealed and kept in a shaker at $25 \mathrm{C}$ and $120 \mathrm{rpm}$ for 24 hour, followed by centrifuging the contents at 3500 rpm for $20 \mathrm{~min}$. After centrifugation, methanol extract was filtered using Whatman filter paper No.1. The result methanolic extracts were evaporated to dryness in vacuum condi-tion using a rotaevaporator. After evaporation dried plant extract dissolve in minimum amount of distilled water $(10 \mathrm{ml})$, transferred into a separating funnel and extracted with equal volume of n-butanol (3 times).

\section{Estimation of total saponins:}

Total saponins contents were estimated by prescribed colorimetric methods ${ }^{(18) .} 500 \mu \mathrm{l}$ of solution was taken in different test tubes to which $0.25 \mathrm{ml}$ of vanillin reagent $(8 \%, \mathrm{w} / \mathrm{v}$ in $99.9 \%$ ethanol) was added. Test tubes were placed in ice-cold water bath and $2.5 \mathrm{ml}$ of $72 \%(\mathrm{v} / \mathrm{v})$ sulphuric acid was added slowly on the inner side of the wall. After mixing the content in each tube, these were left as such for $3 \mathrm{~min}$. warmed the tubes to $60 \mathrm{C}$ for $10 \mathrm{~min}$ using a water bath and then cooled them in ice-cold water bath. Absorbance was measured at $544 \mathrm{~nm}$ using spectropho-tometer. Quillaja saponin (SigmaAldrich) was used as a reference standard and the 
content of total saponins was expressed as Quillaja saponin equivalents (QS $\mu \mathrm{g} / \mathrm{mg}$ extract).

\section{Determination of antioxidant cont-ent of Balanites aegyptiaca extract by 2, 2-diphenyl- 1-picrylhydrazy(DPPH):}

DPPH assay was measured in methanolic extract. An aliquot of methanolic extract (50 $\mu \mathrm{l})$ was mixed with the ethanol DPPH solution $(0.5 \mathrm{mM}, 0.25 \mathrm{ml})$ and the acetate buffer $(100$ $\mathrm{mM}, \mathrm{pH} 5.5,0.5 \mathrm{ml})$. After standing for 30 min in the dark, the absorbance was measured at $517 \mathrm{~nm}$ against a blank containing absolute ethanol instead of a sample aliquot. The results are expressed as an IC50 value that represents the amount of fruit powder (in $\mathrm{mg}$ ) providing 50\% inhibition of 2,2-diphenyl-1picrylhy-drazylradical (DPPH) ${ }^{(19) .}$

\section{Determination of total flavnoides in Balanites aegyptiaca extract:}

Total flavonoids content was measured in methanolic extract by the aluminum chloride colorimetric assay ${ }^{(20)}$. An aliquot $(1 \mathrm{ml})$ of extracts or standard solution of catechin (20, $40,60,80$ and $100 \mathrm{mg} / \mathrm{l}$ ) was added to $10 \mathrm{ml}$ volumetric flask containing $4 \mathrm{ml}$ of dd $\mathrm{H}_{2} \mathrm{O}$. To the flask was added $0.3 \mathrm{ml} 5 \% \mathrm{NaNO}_{2}$. After 5 min. $0.3 \mathrm{ml} 10 \% \mathrm{AlCl}$, was added. After $6 \mathrm{~min}$, $2 \mathrm{ml} 1 \mathrm{M} \mathrm{NaOH}$ was added and the total volume was made up to $10 \mathrm{ml}$ with $\mathrm{H}_{2} \mathrm{O}$. The solution was mixed well and the absorbance was measured against prepared reagent blank at $510 \mathrm{~nm}$. Total flavonoid content of fruits was expressed as mg catechin equivalents (CE)/100 $\mathrm{g}$ fresh weight. Samples were analyzed in triplicates.

\section{Determination of total proteins in Balanites aegyptiaca extract:}

Digestion was done according to ${ }^{(21)}$.

$1 \mathrm{~g}$ ground sample was weighed into digestion flask, recording weight $(\mathrm{W})$ to nearest $0.1 \mathrm{mg}$. To the flask $16.7 \mathrm{~g} \mathrm{~K} 2 \mathrm{SO} 4,0.01 \mathrm{~g}$ anhydrous copper sulfate, and $0.6 \mathrm{~g} \mathrm{TiO} 2$ was added. Then $20 \mathrm{ml}$ sulfuric acid was added.
Flask placed on preheated burner (adjusted to bring $250 \mathrm{ml}$ water at $25^{\circ} \mathrm{C}$ to rolling boil in 5 min) and heated until white fumes clear bulb of flask, swirled gently (heating continued for $4 \mathrm{~h}$ ).

\section{Distillation:}

Titration flask was prepared by adding $25 \mathrm{ml}$ of $4 \%$ boric acid, 3 to 4 drops kjldahl indicator was added, then the condenser tip was immersed inside boric solution slowly down side of flask, sufficient $40 \%$ sodium hydroxide solution (approximately $80 \mathrm{ml}$ ) was added to make mixture strongly alkali. Immediately flask connected to dist-illation apparatus and distilled at about 7.5 boil rate (temperature set to bring $250 \mathrm{ml}$ water at $25^{\circ} \mathrm{C}$ to boil in $7.5 \mathrm{~min}$ ) until at least $150 \mathrm{ml}$ distillate is collected in titrating flask. Finally, digestion flask and titrating flask were removed from unit.

\section{Titration:}

Standard HCL $0.1 \mathrm{~N}$ was titrated to pink endpoint (color changed from green to pink) and volume was recorded to nearest $0.01 \mathrm{ml}$.

\footnotetext{
Calculation: Percent Nitrogen $\% \mathrm{~N}=$ VHCL $x$ NHCL $\times 0.014 \times 100 / \mathrm{W}$

- $\mathrm{VHCL}=\mathrm{ml}$ standard HCL needed to titrate sample

- NHCL = Normality of HCL

- $\mathrm{W}=$ sample weight

Percent Crude Protein (CP)

$\mathrm{CP}=\% \mathrm{NX} \mathrm{F}$

$\mathrm{F}=6.25$ for all forages and feeds except wheat grains
}

\section{Determination of total carbohydrates in Balanites aegyptiaca extract:}

The phenol sulphuric acid method ${ }^{(22)}$ was used to estimate carbohydrates

Materials: Phenol 5\% redistilled (reagent grade) phenol $(50 \mathrm{~g})$ dissolved in water and diluted to one liter, Sulphuric acid $96 \%$ reagent grade, Standard glucose: stock $-100 \mathrm{mg}$ in 100 
$\mathrm{ml}$ of water. Working standard $-10 \mathrm{ml}$ of stock diluted to $100 \mathrm{ml}$ with distilled water.

7. Determination of surface elements in Balanites aegyptiaca extract by electron microscope:

A part of balanites aegyptiaca were coated with a thin film of gold-palladium on the observed surface under high vacuum conditions and the internal structure was examined by a JEOL scanning electron microscope type JXA 840A, Japan. Scanning electro micro-graphs of these samples were taken at magnifications of $500 \mathrm{X}$.

\section{Second Part: Chemical studies on Balanites aegyptiaca extraction in vitro:-}

\section{Determination of anti-inflammatory activity of Balanites aegyptiaca extract:}

Raw murine macrophages (RAW 264.7) were seeded in 96 -well plates at $0.5 \times 10^{5}$ cells / well for 2 hours in RPMI without phenol red. The cells were stimulated with lip polysaccharides (LPS) with final concentrations of $100 \mu \mathrm{gmL}^{-1}$. Stimulated cells after two extra hours were either treated with serial concentrations of the tested samples, Dexamethasone $(50 \mathrm{ng} / \mathrm{ml})$ as a potent antiinflammatory, left with the (LPS) alone, or left untreated at all as a negative control. After total 24 hours time interval the supernatants were removed and assessed for Nitric oxide (NO). Nitrite accumulation was used as an indicator of NO production using a microplate assay based on the Griess reaction. This method was done according to ${ }^{(23)}$ by using spectrophoto-meter at $540 \mathrm{~nm}$.

\section{Determination of antitumor activity of Balanites aegyptiaca extract on breast cell line:}

\section{Measurement of potential cytotoxicity by SRB assay:}

Potential cytotoxicity of (B. a.) extract was tested using the method of ${ }^{(24) .}$
Cells were plated in 96-multiwell plate $\left(10^{4}\right.$ cells/well) for $24 \mathrm{hrs}$ before treatment with the compound to allow attachment of cell to the wall of the plate.

Different concentration of (B. a.) extract ( 0 , $5,12,25,50 \mathrm{ug} / \mathrm{ml}$ ) were added to the cell monolayer triplicate wells were prepared for each individual dose.

Monolayer cells were incubated with (B. a.) extract for $48 \mathrm{hrs}$ at $37^{\circ} \mathrm{C}$ and in atmosphere of $5 \% \mathrm{CO}_{2}$.After $48 \mathrm{hrs}$, Cells were fixed, washed and stained with Sulfo-Rhodamine-B stain.

Excess stain was washed with acetic acid and attached stain was recovered with Tris EDTA buffer. Color intensity was measured in an ELISA reader.

The relation between surviving fraction and drug conc. is plotted to get the survival curve of each tumor cell line after the specified compound. Results

The surface element profile of the total extract of Bal. fruit was impressive, and contained some key elements such as, $\mathrm{Fe}, \mathrm{Zn}, \mathrm{Ca}, \mathrm{Al}, \mathrm{K}, \mathrm{Mg}, \mathrm{Cl}$, $\mathrm{Si}, \mathrm{O}$ and $\mathrm{C}$. It may be concluded that the fruits of Bal. contribute to nutrient intake by the consuming populations in Africa and Middle East.

Results of antitumor activity of Balanites aegyptiaca extract on human breast adinocarcinoma cell line (MCF-7): B. a. extract demonstrated high antiproliferation activity against breast cell line (MCF-7) resulted in IC50 $=21.2 \mathrm{ug} / \mathrm{ml}$.

\section{Discussion}

By using spectrophotometric assay total polyphenols in Balanites aegyptiaca (B. a.) extract which was found to be 77.5 $(\mathrm{mgGAE} / \mathrm{g})$. These results are in accordance with (1) who reported that the phytochemical analysis for methanol extract of (B. a.) fruit revealed the presence of saponin, terpenoids, phenolic compounds and alkaloids, with 
considerable quantities of total phenolics ( $212 \pm$ $2.6 \mathrm{mg} \mathrm{GAE} / \mathrm{g}$ ).

Also, are in line with ${ }^{(25)}$ reported that phytochemical investigation on leaves of (B. a.) methanolic extract showed the presence of saponins, tanins, phenols and anthraquinones. Therefore, in the light of these results (B. a.) showed antioxidant activity. These results also revealed that the methanolic extract of (B. a.) fruit was free radical scavengers, acting possibly as primary antioxidants.

Total phenolic acids also was evaluated by HPLC which revealed that the presence of some compounds such as Catechin $6.78(\mathrm{mg} / \mathrm{g})$ $\approx 33.9 \mathrm{mg} / \mathrm{ml} \quad, \quad$ Gallic acid $1.54(\mathrm{mg} / \mathrm{g})$ $\approx 7.7 \mathrm{mg} / \mathrm{ml}, \quad$ Chlorogenic $\quad 1.45(\mathrm{mg} / \mathrm{g})$ $\approx 7.25 \mathrm{mg} / \mathrm{ml}$, Vanillic $4.34(\mathrm{mg} / \mathrm{g}) \approx 21.7 \mathrm{mg} / \mathrm{ml}$, p-Cumaric $2.6(\mathrm{mg} / \mathrm{g}) \quad \approx 13 \mathrm{mg} / \mathrm{ml}$, Ferulic $3.34(\mathrm{mg} / \mathrm{g}) \approx 16.7 \mathrm{mg} / \mathrm{ml}$ and Rutin $3.67(\mathrm{mg} / \mathrm{g})$ $\approx 18.35 \mathrm{mg} / \mathrm{ml}$.

These results are in agreement with ${ }^{(26)}$ who reported the presence of Chlorogenic acid $<0.2$, $p$-Coumaric acid 21.26 \pm 0.63 ,Ferulic acid 7.09 \pm 0.07and Rutin 425.71 \pm 2.15 in HPLC chromatogram of O.basilicum sample . Also, (27) stated that Rutin and isorhamnetin were identified by HPLC finger-print chromatograms of active Extracts The concentrations of rutin in Balanites aegyptiaca two extracts were found to be 0.239 and $0.031 \%$ and those of isorhamnetin were 0.004 and $0.007 \%$, respectively.

Total saponins found in (B. a.) extract was $184.57 \pm 2.71 \mathrm{mg} / \mathrm{ml} \approx 36.91 \mathrm{mg} \mathrm{QS} / \mathrm{g}$, this result showed that (B. a.) total extract contained saponins which are in agreement with ${ }^{(8)}$ who reported that (B. a.) leaves and root bark may be used to reduce blood pressure and cholesterol level in blood. This result could be due to the presence of saponins in the plant parts.

Balanites aegyptiaca extract is considered as a potential source of natural antioxidant, and incorporation of these extracts into foods could enhance their nutritional and antioxidant potentials. Our data corroborate those reported by ${ }^{(28)}$.
DPPH radicals are widely used to investigate the scavenging activity of natural compounds. These free radicals are stable in ethanol and show maximum absorbance at $517 \mathrm{~nm}$. When DPPH radicals encounter a protondonating substance such as an antioxidant, the radicals are scavenged and their absorbance reduced ${ }^{(28) .}$

Free radical scavenging effects of total extract of fruit of (B. a.) was measured with ascorbic acid as standard compound by using DPPH method which results in each gram of Bal. dry matter contained $10 \mathrm{mg}$ of ascorbic acid so total extract of Balanites aegyptiaca (L.) Delile are more effective as antioxidant $10 \mathrm{mg}$ (ascorbic acid) /g (dry matter).

This result could be due to that the fruit mesocarp contains a large variety of phytochemicals amongst which are the pregnane glycosides, coumarins, flavor-noids, 6-methyldiosgenin and furostanol saponins ${ }^{(53)}$ and ${ }^{(54)}$ who reported that (B. a.) fruit extract could be electron donors, and hence can react with free radicals to convert them to more stable products and terminate the radical chain reaction.

Also, (52) suggested that it may also be possible that the combined effect (synergistic or antagonistic) of saponins with other phytochemicals may responsible for observed antioxidant activity where earlier studies attributed the antioxidant activity of plants to the presence of these secondary metabolites ${ }^{(51) .}$

Moreover, Kumawat et al., (2012b) (31) reported that alcoholic extract of (B. a.) could be a potential natural source of antioxidants and could have greater importance as therapeutic agent in preventing or slowing oxidative stress related degenerative diseases.

Flavnoids of Total extract of balanities aegyptiaca fruit was found to be $(9.5 \mathrm{mg}$ CAT/g dry matter) in which catchine was used as standard compound. These results are in accordance with ${ }^{(28)}$ who showed that aqueous extracts of (B. a.) fruit showed the presence of flavnoids $(3.21 \pm 0.59 \%)$ fresh extract and for boiled extract was $(3.80 \pm 0.49 \%)$ and ${ }^{(29)}$ who 
reported that the plants investigated are rich in alkaloids, flavonoids, steroids, terpenoids. which are also in analogy with previous reports of ${ }^{(6)}$.

Percentage of crude protein of (B. a.) extract was found to be $3.15 \pm 0.17 \%$. These results are in agreement with ${ }^{(5)}$ who revealed that a protein content of (B. a.) fruit pulps was found to be $9.06 \mathrm{~g} 100 \mathrm{~g}-1$

There were $92.97 \mathrm{mg}$ glucose/g dry of total carbohydrates which present in (B. a.) extract. These results are in agreement with ${ }^{(30)}$ who reported that phytoconstituents were isolated from plant showed the presence of fluorescence compounds, carbohydrates, protein \& amino acid, glycosides, saponin, tannins and flavonoids. As several factors may explain these variations such as the impact of soil and climatic conditions, the maturity of analyzed fruits, or changes in analysis methods used reported by ${ }^{(5)}$.

The surface element profile of the (B. a.) fruit total extract was impressive, and contained some key elements such as, Fe, Zn, Ca, Al, K, $\mathrm{Mg}, \mathrm{Cl}, \mathrm{Si}, \mathrm{O}$ and $\mathrm{C}$. It may be concluded that the fruits of (B. a.) contribute to nutrient intake by the consuming populations in Africa and Middle East, who revealed that Phytochemical screening indicated the presence of saponin, flavonoids, steroids, alkaloids and cardiac glycosides in the fruit mesocarp of (B. a.).

These results are in agreement with ${ }^{(32)}$ who reported that Seven of the most important medicinal plants in the literature on Egyptian traditional and popular medicine are 'Halfa barr' (Cympobogon proximus), 'Salam' (Acacia ehrenbergiana), 'Kharaaz' (Acacia albida), 'Ghalqa' (Pergularia tomentosa), 'Argel' (Solenostemma arghel), 'Hegleeg' (Balanites aegyptiaca) and 'Handal' (Citrullus colocynthis). Contained minor elements ( $\mathrm{Zn}, \mathrm{Cu}, \mathrm{Se}, \mathrm{Mn}$ and $\mathrm{Fe})$ and major elements ( $\mathrm{K}, \mathrm{Na}, \mathrm{Ca}, \mathrm{Mg}$. The highest concentration was that of zinc, ranging from 15.4 to 73.7 (mg kg_1). Although some plants were found to accumulate elements, their contents are still below the international safety limits for both human and animal consumption.
Potassium weight was $1.53 \%$, it helps to maintain body weight and regulate water and electrolyte balance in the blood and tissues ${ }^{(33) .}$

The calcium weight was determined to be $6.41 \%$. Calcium helps in the regulation of muscle contraction require-ed by children, infants and foetuses for bones and teeth development ${ }^{(34),}$ the zinc weight was given as $0.31 \%$. Zinc is said to be an essential trace element for protein and nucleic acid synthesis and normal body development (35). Zinc also stimulates the activity of vitamins, and the formation of red and white blood cells ${ }^{(36) .} \mathrm{Zinc}$ plays a role in improving male fertility, The iron weight was given as $1.06 \%$, and compares favorably with other vegetables. Iron is said to be an important element in the diet of pregnant women, nursing mothers, infants, convalescing patients and the elderly to prevent anemia and other related diseases ${ }^{(37) \text {. }}$

The magnesium weight was found to be $0.49 \%$. Magnesium plays fund-amental roles in most reactions involving phosphate transfer. It is believed to be essential in the structural stability of nucleic acids. It plays a significant role in the intestinal absorption of electrolyte in the body. Its deficiency in man includes severe diarrhea and persistent migraines ${ }^{(38)}$.

The different in vitro chemical activities of (B. a.) extract were done by first determination of the anti-inflamma-tory activity for (B. a.) extract (activity on NO production) fig (5).

Total (B. a.) extract showed strong antiinflammatory effect at all used concentration range from $500-62.5 \mu \mathrm{g} / \mathrm{ml}$ which inhibited nitric oxide to levels more than that of Dexamethasone (strong anti-inflammatory drug) especi-ally at range $250-62.5 \mu \mathrm{g} / \mathrm{ml}$ as (B. a.) extract at concentration $62.5 \mu \mathrm{g} / \mathrm{ml}$ showed inhibition of NO production by $60 \%$ compared to LPS (lip poly-saccharides which induced inflamma-tion) group as positive control group thus the extract was considered as a potent antiinflammatory agent. These results could be due to the presence of saponins which has antiinflammatory properties. This is consistent with 
the report of ${ }^{(39)}$ who showed that (B. a.) fruit is used in the treatment of inflammation.

Furthermore, the presence of stero-ids on the leaves and root bark of (B. a.) fruit suggest that the plant part may be used as antiinflammatory and analgesic agents reported by (40).

These results are in agreement with ${ }^{(8)}$ who revealed that the leaves and root bark of (B. a.) fruit can be used for anti-inflammatory treatment.

Seconed determination of the antitumor activity for (B. a.) extract against human breast cancer cell line (MCF-7) which illustrated as shown in fig (6) cleared that (B. a.) extract demonstrated high antiproliferation activity against breast cancer cell line (MCF-7) resulted in IC $50=21.2 \mu \mathrm{g} / \mathrm{ml}$.

These results could be due to the saponins of ethanol extract of Balanites aegyptiaca which was able to stabilize reactive oxygen species by reacting with them and oxidizes subsequently to more stable and less reactive radicals. In this respect saponins in (B. a.) play an important role as antioxidant for prevention of oxidative damage $^{(41)}$.

Rejinold et al., (2011) ${ }^{(42)}$ showed that saponins are well known for their potential anticancer activity. However, the reported value for saponin is $50 \mathrm{~g} / \mathrm{ml}$ to show toxicity against cancer cells

The selective inhibition of the growth of tumor has been observed by triterpenoid saponins (avicins from Acacia victoriae) by cell cycle arrest in human breast cancer cell line and apoptosis in leukaemia cell line ${ }^{(43)}$.

Saponin (triterpenoidor steroid)-induced apoptosis is primarily caused by stimulating the cytochrome c-caspase 9-caspase 3 pathway in the human cancer and other cell lines $(44,45,46)$.

Davis and Matthew et al., (2000) (47), explained the antitumor activity of (B. a.) extract was to the flavonoids found in the extraction which are known to inhibit production of heat shock proteins in several malignant cell lines, including breast cancer, leukemia, and colon cancer

These results are in agreement with ${ }^{(48)}$ who reported that the compoundsSAP-1016(3b-O-bD-xylopyranosyl-(1-3)-b-D-glucopyranosyl-(14)-[a-L- rhamnopyranosyl-(1-2)]-b-Dglucopyranoside) exhibited potent antiproliferative activity against MCF-7 human breast cancer cells and HT-29 human colon cancer cells, with IC50 values of $2.4 \pm 0.35$ and $3.3 \pm 0.19 \mathrm{mmol} / \mathrm{l}$, respectively, compared with dioscin, one of the most potent cytotoxic spirostane saponins, with IC50 values of $3.1 \pm 0.39$ and $4.9 \pm 0.32 \mathrm{mmol} / \mathrm{l}$, respectively.

It is reviewed that fixed oil of Balanites aegyptiaca exhibited anticancer activity against lung, liver and brain human carcinoma cell lines. It also had antimutagenic activity against Fasciola gigantica induced mutagenicity. ${ }^{(12)}$.

Elie et al., (2010) ${ }^{(11) .}$ Showed that saponins extracted from Balanites aegyptiaca have potent anti cancer activity against MCF-7 human breast cancer cells and HT-29 human colon cancer cells.

For diosgenyl saponins the presence of an-1Rhap-( $1 \rightarrow 2)-\beta$-d-Glcp sequence at C-3 was considered beneficial for cytotoxicity activity ${ }^{(49)}$. In addition, ${ }^{(50)}$ reported that balanitoside, extracted from Balanites aegyptiaca, posses an $\alpha$-1-Rhap-( $1 \rightarrow 2)-\beta$-d-Glc $p$ sequence at C-3 which mean that balanitoside have cytotoxicity properties that were in line with the current results.

\section{REFERENCES}

1- Rajakannu S, Sritharan UR and Rajiv GS (2012). Phytochemical Screening, Antimicrobial Activity and In Vitro Antioxidant Investigation of Methanolic Extract of Seeds from Helianthus annuus L. Chemical Science Review and Letters;1(1):30-34. ISSN 2278-6783. 
2- Jones D.P., (2006): Redefining oxidative stress. Antioxid Redox Signal8:1865-1879.

3- Mackenzie R.M., Salt I.P., Miller W.H., Logan A., Ibrahim H.A., Degasperi A., Dymott J.A., Hamilton C.A., Murphy M.P., Delles C, and Dominiczak A.F., (2013): Mitochondrial reactive oxygen species enhance AMP-activated protein kinase activation in the endothelium of patients with coronary artery disease and diabetes. Clinical Science (London) journal 124:403-411.

4- Airaki M., Leterrier M., Mateos R.M., Valderrama R., Chaki M., Barroso J.B., Del Rio L.A., Palma J.M., and Corpas F.J., (2011): Metabolism of reactive oxygen species and reactive nitrogen species in pepper (Capsicum annuum L.) plants under low temperature stress. Plant Cell Environment journal. 35(2):281-95.

5- Sagna MB, Diallo A, Sarr PS, Ndiaye O, Goffner D and Guisse A (2014). Biochemical composition and nutritional value of Balanites aegyptiaca (L.) Del fruit pulps from Northern Ferlo in Senegal. African Journal of Biotechnology; 13: 336-342.

6- Yadav JP and Panghal $M$ (2010). Balanites aegyptiaca (L.) Del. (Hingot): a review of its traditional uses, phytochemistry and pharmacological properties. International Journal of Green Pharmacy; 4:140-146.

7- Daya LC and Vaghasiya HU (2011). A review on Balanites aegyptiaca Del (desert date): phytochemical constituents, traditional uses, and pharmaco-logical activity Pharmacogn Review; 2011; 5(9): 55-62.

8- Tula MY, Dancha TB, Iruolaje FO and Onyeje GA (2014). Studies on Phytochemical Constituents and Antibacterial Potentials of Extracts of Balanites aegyptiaca (Del.) Parts on Antibiotic Resistant Bacterial Isolates. European Journal of Medicinal Plants; 4: 854-864.
9- Chothani DL, Vaghasiya HU (2011). A review on Balanites aegyptiaca Del (desert date): phytochemical constituents, traditional uses, and pharmacological activity. Phcog. Rev.; 5 (9): 55-62.

10- Meda NT, Lamien-Meda A, Kiendrebeogo M, Lamien CE, CoulibalyAY and MillogoRasolodimby J (2010). In vitro antioxidant, xanthine oxidase and acetylcholinesterase inhi-bitory activities of Balanites aegyptiaca (L.) Del. (Balanit-aceae). Pakistan Journal of Biological Science; 13:362-368.

11- Elie BY, Shimon BS, Noa G, Bishnu PC and Rui H (2010). Anti proliferative activity of steroidal saponins from Balanites aegyptiaca - An in vitro study. Phytochemistry letters; 4: 43-47.

12- Hanan AA, Ayman A, Farghaly MM, Abd E A and Ali MA (2010). Phytochemical investigation and medicinal evaluation of fixed oil of Balanites aegyptiaca fruits (Balantiaceae). Journal of Ethnopharmacology.; 127: 495-501.

13- Yuhua Li, Lei Fan, Yang Sun, Xia Miao, Feng Zhang, Jin Meng, Jin Han, Dian Zhang, Rong Zhang, Zhenggang Yue and Qibing Mei (2014). Glycoprotein inhibition and apoptosis augmentation, Journal of ethnopharmacology; In press: DOI: 10.1016/j.jep.2014.04.049.

14- Thakare M (2004). Pharma-cological screening of some medicinal plants as antimicrobial and feed additive. Masters' Thesis. Department of Animal and Poultry Science, Virginia Polytechnic Institute and State University, Blackburg, Virginia, USA.

15- Molla E., Giday M, and Erko B.,(2013): Laboratory assess-ment of the molluscicidal and cercariacidal activities of Balanites aegyptiaca, Asian Pacific Journal of Tropical Biomedicine; 3(8): 657-662.

16- De Leonardis A, Macciola $V$ and Di Domenico N (2005). A first pilot study to 
produce a food antioxidant from sunflower seed shells (Helianthus annuus), European journal of lipid science and technology; 107: 220-227.

17- Singleton VL and Rossi Jr JA (1965). Colorimetry of total phenolics with phosphor-molybdic-phosphotungstic acid reagents. American Journal of Enology and Viticulture; 16: 144-158.

18- Goel N, Sirohi SK and Dwivedi J (2012). Estimation of Total Saponins and Evaluate Their Effect in vitro on Methanogenesis and Rumen Fermentation Pattern in Wheat Straw Based Diet. Journal of Advanced Veterinary Research; 2: 120-126.

19- Kolečkár V, Jun D, Opletal L, Jahodár L and Kuča L (2007). Assay of radical scavenging activity of antidotes against chemical warfare againts by DPPH test using sequential injection technique. Journal of Applied Biomedicine.; 5: 8184.

20- Zhishen J, Mengcheng $T$ and Jianming W (1999). The determination of flavonoid contents in mulberry and their scavenging effects on superoxide radicals. Food Chemistry; 64: 555-559.

21- AOAC (2000). Official Methods of Analysis of AOAC International, $17^{\text {th }}$ (ed). North Fredric avenue Gaithersburg, Maryland, USA.

22- BeMiller J. N (2010): Carbohydrate analysis. Ch. 10. In: Nielsen S. S. (ed) Food Analysis, $4^{\text {th }}$ (ed). Springer, New York.

23- Green LC, Wagner DA, Glogowski J, Skipper PL, Wishnok JS and Tannenbaum SR (1982). Analysis of nitrate, nitrite, and $\left({ }^{15} \mathrm{~N}\right)$ nitrate in biological fluids, Analytical Biochemistry journal; 126: 131-138

24- Skehan P, Storeng R, Scudiero D, Monks A, McMahon J, Vistica D, Warren JT, Bokesch H, Kenney S and Boyd MR (1990): New coloremtric cytotoxicity assay for anti-cancer drug screening Journal of the National Cancer Institute.; 82: 1107-1112.
25- Doughari JH, Pukuma MS, De N (2007). Antibacterial effects of Balanites aegyptiaca L. Del. and Moringa oleifera Lam. On Salmonella typhi. African journal of biotehnology; 6: 2212-2215.

26- Vlase L, Benedec D, Hanganu $D$, Damian G, Csillag I, Sevastre B, Mot A, Silaghi-Dumitrescu $\mathbf{R}$ and Tilea I (2014). Evaluation of Antioxidant and Antimicrobial Activities and Phenolic Profile for Hyssopus officinalis, Ocimum basilicum and Teucrium chamaedrys. Molecules journal; 19: 5490-5507.

27- Abdel Motaal A, Shaker S and Haddad PS (2012). Antidiabetic Activity of Standardized Extracts of Balanites aegyptiaca Fruits using Cell-based Bioassays. Pharmacognosy Journal; 4: 20-24.

28- Amadou I, Guo-Wei L, Yong-Hui S and Sun J (2011). Reducing, radical scavenging, and chelation properties of fermented soy protein meal hydrolysate by Lactobacillus plantarum Lp6. International Journal of Food Properties; 14: 654-665.

29- Vijay $\mathbf{P}$, Nivedita and Bellundagi A (2013). Ethanobotany and qualitative phyotochemical analysis of some Indian medicinal plants. International Journal of Chemical and Pharmaceutical Sciences; 4: 2.

30- Kumawat BK, Gupta M, Chand T and Singh Y (2012a). Prelimenary Phytochemical Investigation on Leaves of Balanites Aegyptiaca (L.) Delile. Research Journal of Pharmaceutical, Biological and Chemical Sciences RJPBCS; 3: 762.

31- Kumawat BK, Gupta M, Chand T and Singh Y (2012b). Free radical scavenging effect of various extracts of leaves of Balanites aegyptiaca(L.) Delile by DPPH method, Asian Journal of Plant Science Research.; 2:323-329

32- Sheded MG, Pulford ID and Hamed AI (2006). Presence of major and trace elements in seven medicinal plants growing in the South-Eastern Desert, 
Egypt. Journal of Arid Environments; 66: 210-217.

33- NRC (1989). National Research Council Recommended Dietary Allowance, National Academy Press, Washington D. C.

34- Margaret L and Vickery B (1997). Plant Products of Tropical Africa. Macmillan in College ed. London.

35- Melaku U, Clive EW and Habtamon F (2005). Content of zinc, iron, calcium and their absorption inhibitors in foods commonly consumed in Ethiopia. Journal of Food Composition and Analysis; 18: 803-817.

36- Claude B and Paule S (1979). The Manual of Natural Living (1st ed.). Biddles Ltd., Guildford, Surrey; 98-101.

37- Oluyemi EA, Akilua AA, Adenuya AA and Adebayo MB (2006). Mineral Contents of Some Commonly Consumed Nigerian Foods. Science Focus; 11: 153157.

38- Appe LJ (1999). Nonpharma-cologic Therapies that Reduce Blood Pressure. A fresh Perspective. Clinical Cardiology; 1111-1115.

39- Kubmarawa D, Ajoko GA, Enwerem NM and Okorie DA (2007). Preliminary phyto-chemical and antimicrobial screening of 50 medicinal plants of Nigeria. African Journal of Biotechnology.; 6:1690-1696.

40- Singh AP (2006). Short Review: Distribution of Steroid like Compounds in Plant Flora. Pharmacognosy Magazine; 2:87-89.

41- Mohan VR, Suky TMG, Parthipan B and Kingston $C$ (2011). AntiInflammatory Activity of Aerial part of Balanites aegyptiaca (L.) Del against Carrageenan induced Paw Oedema. International Journal of PharmTech Research; 3: 639-643.

42- Rejinold NS, Muthunarayanan M, Muthuchelian K, Chen-nazhi KP, Shanti V and Jayakumara NR (2011). Saponin-loaded chitosan nano-particles and their cytotoxicity to cancer cell lines in vitro. Carbohydrate Polymers; 84: 407-416.

43- Mujoo K, Haridas V, Hoffmann JJ, Wachter GA, Hutter LK and Lu Y (2001). Triterpenoid saponins from Acacia victoriae (Bentham) decrease tumor cell proliferation and induce apoptosis. Cancer Research; 61: 54865490.

44- Cai J, Liu M, Wang Z and Ju Y (2002). Apoptosis induced by dioscinin Hela cells. Biological and Pharmaceutical Bulletin; 25: 193-196.

45- Liu WK, Xu SX and Che CT (2000). Anti-proliferative effect of ginseng saponins on human prostate cancer cell line. Life Sciences; 67: 1297-1306.

46- Yui S, Ubukata K, Hodono K, Kitahara M, Mimaki Y and Kuroda M (2001). Macrophage-oriented cytotoxic activity of novel triterpene saponins extracted from roots of Securidaca inappendiculata. International Immunopharmaco-logy; 1: 1989-2000.

47- Davis WL and Matthew SB (2000). Antioxidants and cancer III: quercetin,' Alternative Medicine Review; 5: 196208.

48- Harlev E, Nevo E, Ephraim P, Lansky EP, Lansky S and Bishayeed A (2012). Anticancer attributes of desert plants: a review. Anticancer Drugs; 23:255-71.

49- Irma P, Agnieszka G, and Danuta S (2010). Saponins as cytotoxic agents: a review. Phytochemistry-journal-Elsevier. 9: 425-474.

50- Al-Ghannam SM, Ahmed HH, Zein N and Zahran F (2013). Antitumor Activity of Balanitoside Extracted from Balanites aegyptiaca Fruit. Journal of Applied Pharma-ceutical Science; 3: 179191.

51- Akharaiyi FC (2011). Antibacterial, Phytochemical and Antioxidant activities of Datura metel. International Journal of Pharmacology Technology Research; 3: 478-483.

52- Meshram RL, Umbarkar SN and Meshram $R$ (2011). Comparative evaluation for in vitro Antioxidant 
activity from Artocarpus heterophyllus Lamk andBalanites aegyptiaca L. International Journal of Pharm Tech Research.; 2011,3: 2006-2010.

53- Kamel MS (1998). A furostanol saponin from fruits of Balanites aegyptiaca. Phytochemistry; 48: 755-757.
54- Sarker SD, Bartholomew B and Nash RJ (2000). Phyto-chemical communication Alka-loids from Balanites aegyptiaca. Fitoterapia; 71: 328-330.

Table (1): Phenolic acids of Balanites aegyptiaca total extract by HPLC.

\begin{tabular}{lc}
\hline phenolic compound & conc $(\mathbf{m g} / \mathbf{g})$ \\
\hline Catechin & 6.78 \\
Gallic acid & 1.54 \\
Chlorogenic & 1.45 \\
Vanillic & 4.34 \\
p-Cumaric & 2.6 \\
Ferulic & 3.34 \\
Rutin & 3.67 \\
\hline
\end{tabular}

Table (2): Results of antioxidant activity.

\begin{tabular}{ll}
\hline \multicolumn{1}{c}{ Content } & \multicolumn{1}{c}{ Amount } \\
\hline 1. Total Phenolics & $77.5(\mathrm{mg} \mathrm{GAE} \mathrm{matter}) \approx 387.5(\mathrm{mg} \mathrm{GAE} / \mathrm{ml})$ \\
2. Total Saponins & $184.57 \pm 2.71(\mathrm{mg} \mathrm{Qs} / \mathrm{ml}) \approx 36.91(\mathrm{mg} \mathrm{Qs} / \mathrm{g})$ \\
3. (DPPH) assay & $10 \mathrm{mg}($ ascorbic acid $) / \mathrm{g}($ dry matter $)$ \\
4. Flavnoids & $9.5 \mathrm{mg} \mathrm{CAT} / \mathrm{g}$ dry matter $\approx 47.5 \mathrm{mgCAT} / \mathrm{ml}$ \\
\hline
\end{tabular}

Table (3): Results of nutritional value.

\begin{tabular}{ll}
\hline \multicolumn{1}{c}{ Content } & \multicolumn{1}{c}{ Amount } \\
\hline Total Proteins & $3.15 \pm 0.17 \% \mathrm{in} \mathrm{ml} \approx 0.63 \%$ in $\mathrm{g}$ dry matter \\
Total & $464.87 \pm 0.89 \mathrm{mg}$ (glucose) $/ \mathrm{ml} \approx 92.97 \mathrm{mg}$ \\
Carbohydrates & $($ glucose $/ \mathrm{g}($ dry matter $)$ \\
\hline
\end{tabular}

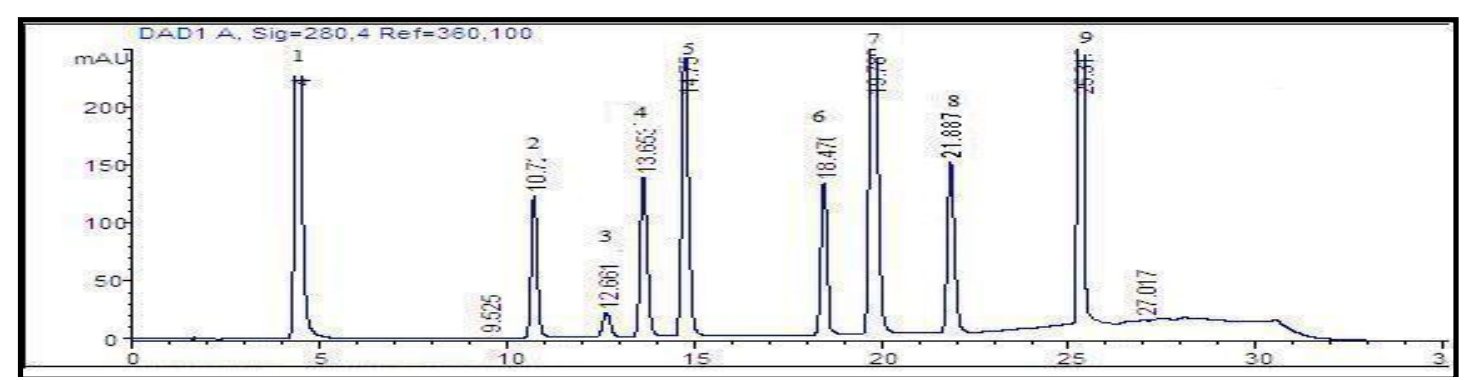

Fig. (1): Typical HPLC chromatogram of phenolic acids; (1) catachin, (2) gallic acid, (3) chlorogenic acid, (4) caffic acid, (5) vanillic acid, (6) p-cumaric acid, (7) ferulic acid, (8) rutin, (9) cinnamic acid. 


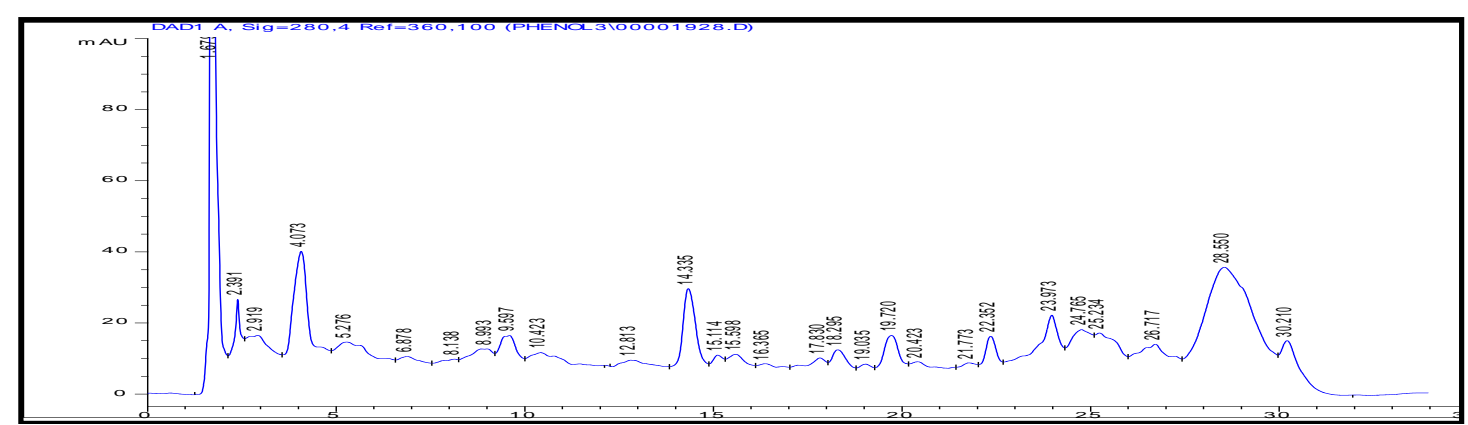

Fig (2): HPLC of phenolic contents in Balanites aegyptiaca total extract.

Results of surface elements in Balanites aegyptiaca extract by electron microscope:

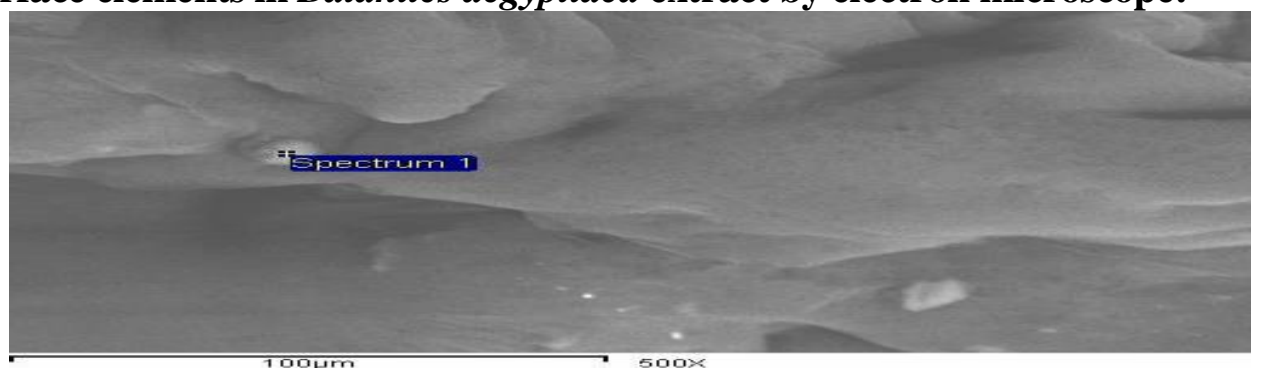

Fig (3): Section in surface of Balanites aegyptiaca extract.

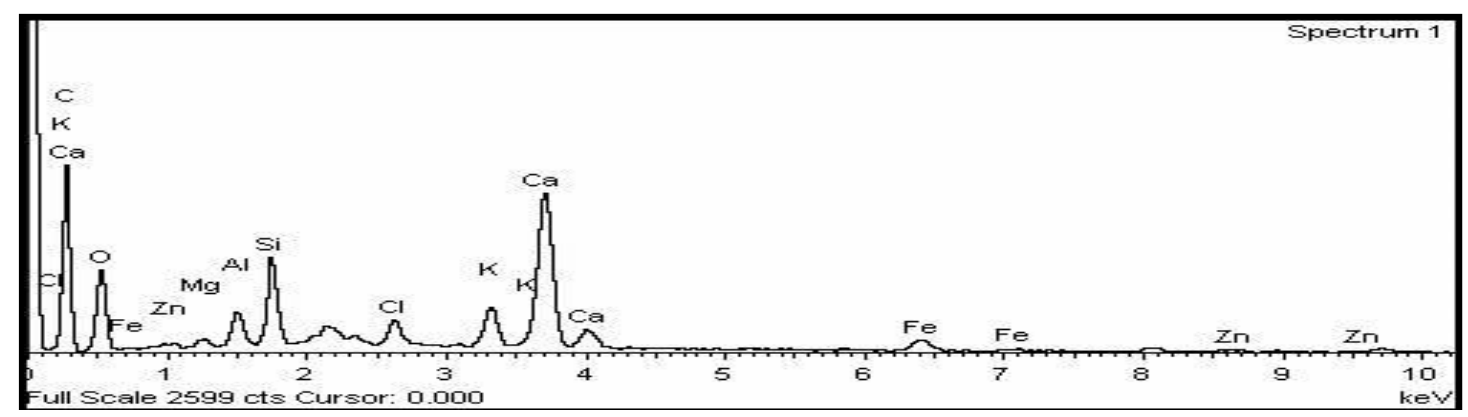

Fig (4): Balanites aegyptiaca extract total surface element.

Table (4): The different surface element weight $\%$ and atomic $\%$ of Balanites aegyptiaca extract.

\begin{tabular}{ccc}
\hline Element & Weight\% & Atomic\% \\
\hline C K & 48.36 & 59.81 \\
O K & 36.37 & 33.77 \\
Mg K & 0.49 & 0.30 \\
Al K & 1.35 & 0.74 \\
Si K & 3.20 & 1.69 \\
Cl K & 0.92 & 0.39 \\
K K & 1.53 & 0.58 \\
Ca K & 6.41 & 2.38 \\
Fe K & 1.06 & 0.28 \\
Zn K & 0.31 & 0.07 \\
Totals & 100.00 & \\
\hline
\end{tabular}




\section{Results of anti-inflammatory activity of Balanites aegyptiaca extract:}

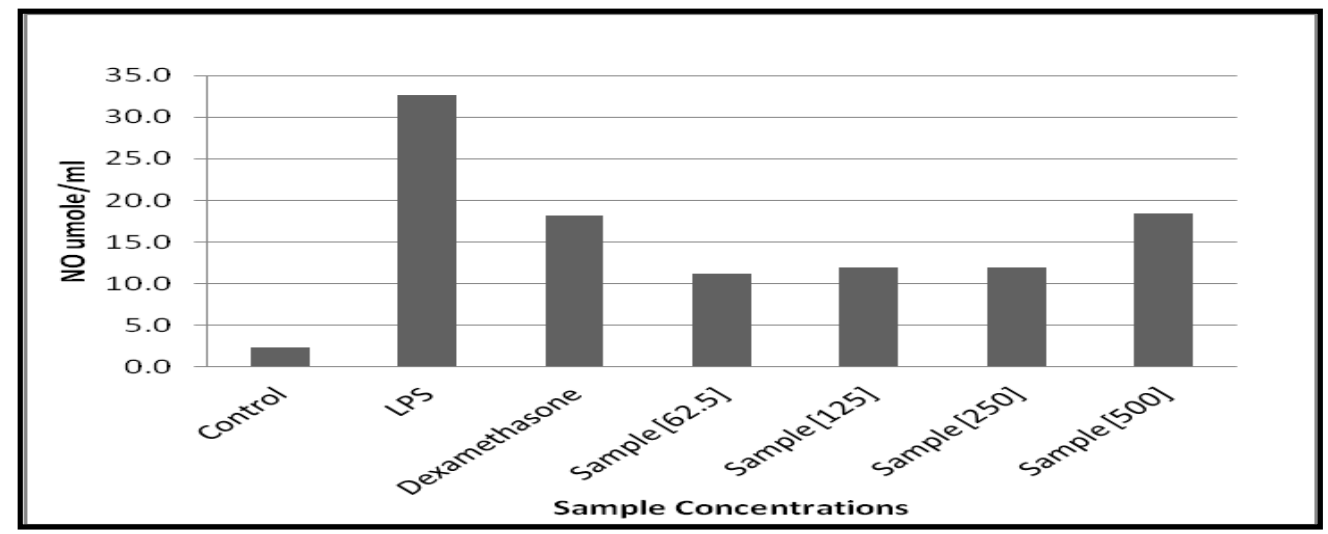

Fig (5): Anti-inflammatory activity of Balanites aegyptiaca extraction compared to LPS and Dexamethasone

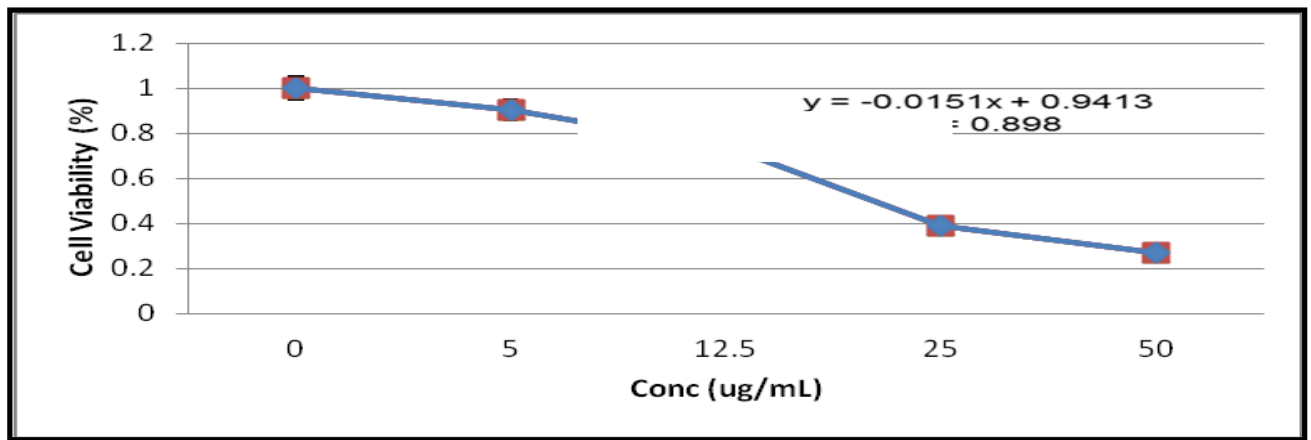

Fig (6): anti tumor activity of Balanites aegyptiaca extract on breast cell line (MCF-7). 